presence, and his undying loyalty to his family, people, and La Causa.

Robert Brischetto

Southwest Voter Research Institute

Charles L. Cotrell

Bro. Thomas Hoffman, S.M.

Henry Flores

Department of Political Science

St. Mary's University

\section{John Albert Vieg}

John A. Vieg, Emeritus Professor of Government at Pomona College, died at home in Claremont, California, on February 12, 1988. Though he was in his eightythird year, the day before his death was spent in a manner typical of his life-long involvement in the world about him. He attended a meeting at Pomona College on the liberal arts curriculum, and at lunch participated in a spirited discussion of the presidential primaries, offering as always various proposals for the reform of the political system. That night he attended a community committee meeting.

A student of Charles Merriam at the University of Chicago in the 1930s, John Vieg managed to combine a strong sense of the empirical rigor and systematization necessary for a genuine discipline of polit$i c a l$ science with a continuing reformist zeal and irrepressible optimism, Not just the good cheer which he had in abundance, but a dedication to a cause lay behind his efforts as a founding father of the Western Political Science Association, which he served as President in 1959-60, or the Southern California Political Science Association, which he was instrumental in founding. He was on the Council of the American Political Science Association in 1947-50, and Vice President of the Association in 1958-59.

Born in Fort Dodge, lowa, Vieg earned an A.B. degree in history from St. Olaf College in 1926. He was Phi Beta Kappa and class president. He continued in his- tory for his master's degree at the University of lowa, and taught history at Burlington Junior College until he headed for the University of Chicago in 1934. For his Ph.D. he switched to political science, the better, he said, "to change the world." Those who knew John realize that such a remark, which can be taken two ways, has to be taken two ways: both as wry selfdeprecation and as an expression of powerful ambition. His doctoral dissertation, on the politics of the Chicago city schools, was later published as a book. A student of public administration, American political parties, and municipal government, his interests expanded to state, national, and international levels. His focus was what today would be called public policy. He had a bemused suspicion of empty philosophical abstractions and liked to bring problems down to a practical level, where alternative solutions for improvement of whatever was being studied could be compared. He began teaching political science at lowa State and quickly found himself Vice-Chairman of the Ames Planning Commission and an officer in what was then the Midwest Conference of Political Scientists.

During World War II he went to Washington as an analyst for the Bureau of the Budget, on loan for a time to the LendLease Administration. After the war he came to Pomona College and served as Chair of the Department of Government until his retirement in 1970. At Pomona he taught almost everything in the curriculum at one time or another, and presided over the gradual expansion of the department from a staff of three to six and beyond. $\mathrm{He}$ was on innumerable committees and, at one critical time in the fifties, served as Chair of the Coordinating Committee in Economics and Government at the Claremont Graduate School. His colleagues uniformly remark on his warm support and encouragement, his helpfulness in many small but important ways, his generosity, and his playful, never caustic, sense of humor, somewhat paradoxically combined with a courtly, dignified manner. He exuded a genuine interest in what students wanted to do and wanted to be. He could chide them gently when they took them. selves too seriously. He paid very close 
attention to the quality of their written English. He kept them thinking, as he did his colleagues, by his relentless questioning. At any meeting, one could always count on john livening things up by asking a penetrating, no-nonsense, question. When he asked friends "What are you doing for the good of the Republic these days?" there would be a twinkle in his eye; but he really expected a serious answer. He had a unique capacity to make us feel better about ourselves at the same time that he made us want to do better.

When he retired from Pomona, eightyone graduates wrote letters of salutation. Most stressed the depth of his concern for the quality of public service, his tolerant acceptance of widely divergent views, and his help in finding them jobs or internships in government, business, or one of the parties. John was a partisan. The local Democratic Club in its obituary notice properly called him "Mr. Democrat." Raised a midwest Republican, he was converted by the Depression into an ardent New Deal Democrat and a supporter of Clarence Streit's Federal Union. But he believed in the two-party system even more than he did the Democratic Party and he helped as many Republican students find their way in politics as he did Democratic students. He could shake his head sadly at the misdeeds of either party. He liked to organize mock conventions, and in the fifties organized an Institute of Practical Politics here that taught students to appreciate politicians and politicians to appreciate students. He helped found what is now the California Center for Education in Public Affairs. Though politics was his life, the congruence of his character transcended passing political changes. In the McCarthy period of the 1950s he was called a dangerous radical because he refused to paint the Soviet Union in sufficiently diabolic tones. In the 1960s he was seen as a neo-conservative because he was disturbed by the disorderliness and irrationality of some student protests. "They do not understand," he said in a reflective 1968 interview, "how difficult it is to transform society ... . on short notice." In fact, throughout these times he remained the reasonable man believing in reasonable solutions. He served seven years as the appointee of Governor Edmund $G$. Brown, Sr., on the California Constitutional Revision Commission, for which the California Senate, in a bipartisan resolution, wisely saluted his "warmth, wit, and wisdom."

In addition to his published dissertation, Vieg was co-author of a number of books, City Manager Government in Seven Cities, 1940; The Future of Government in America, 1942; War-Time Government in Operation, 1943; the venerable Morstein-Marx text, Elements of Public Administration, 1946, 1959; Our Needy Aged, 1954; and Colifornia Local Finance, 1960. John Vieg and Henry Turner, The Government and Politics of California, went through four editions, the last in 1971. Vieg wrote articles in the American Political Science Review, Public Administration Review, Public Opinion Quarterly, and other journals. He wrote a monograph on public administration in India. He held Fulbright Fellowships at the University of Oslo, Norway, in 1952-53, and at the University of Delhi, India, in 1961-62. For a number of years thereafter he was involved in the Senior Fulbright Program for Visiting Scholars in the U.S., chairing two Western conferences. In 1959-60 he became the first Visiting Research Professor in Legislation at the University of California, Berkeley. The Los Angeles Chapter of the American Association for Public Administration gave him its Baughman Award in 1972.

After his supposed retirement, Pomona College twice called him back to teach, once as the William A. Johnson Visiting Professor. He also taught at California Polytechnic University, Pomona; the University of California, Riverside; California State University, Fullerton; and Pitzer College. In 1977, he was appointed by the University of California a professor of government in its Institute of Shipboard Education, and in this capacity he taught aboard the S.S. Universe in its voyage around the world. $\mathrm{He}$ and his wife traveled extensively thereafter. He continued as an active member of numerous other organizations: the International Political Science Association, the National Municipal League, the American Association of University Professors, the Society for Values in Higher Educatiaon, the 
Association to Unite the Democracies (successor to Streit's Federal Union), and the California Committee for Party Renewal. His involvement with Claremont and Southern California causes and organizations was too extensive to chronicle here, but it involved housing for the handicapped, international students, legislative action, Soviet-American friendship, and the United Church of Christ, among other good causes.

Vieg's first wife, Margatet Bjork Vieg, died in 1971. He is survived by his wife, Elizabeth Lam Vieg, sons Karsten Vieg of Sacramento, and Jonathan Vieg of Whittier, California, a brother, and two grandchildren.

Those of us privileged to work with John will remember him as a unique combination of reformer, organization man, perennial teacher, and kindly and generous human being. Reformers are often impatient and unforgiving; but John was both patient and forgiving. Organization men often use people to their own ends; but John was always doing things for people. Only after his death have we learned how many people and groups, not just the Department of Government, thought they were the special beneficiaries of his kindness, good cheer, and deep human affection.

Fred Krinsky Lee McDonald Pomona College 